\title{
Tree Growth and Productivity and Postharvest Fruit Quality in Various Strains of 'Delicious' Apple
}

\author{
Esmaeil Fallahi' ${ }^{1}$ Brenda R. Simons ${ }^{2}$, John K. Fellman ${ }^{3}$, Mark A. Longstroth ${ }^{4}$, \\ and W. Michael Colt ${ }^{5}$ \\ Department of Plant, Soil, and Entomological Sciences, Parma Research and Extension Center, \\ University of Idaho, 29603 U of I Lane, Parma, ID 83660 \\ Delmer O. Ketchie ${ }^{6}$ \\ Tree Fruit Research Center, Washington State University, Wenatchee, WA 98801
}

Additional index words. Malus domestica, storage

\begin{abstract}
Twenty-six strains of 'Delicious' apple (Malus domestica Borkh.) were evaluated over several years for growth, yield, and fruit quality at harvest and after 6 months of storage. 'August Red', 'Rose Red', and 'Sharp Red' had larger trunk cross-sectional area (TCSA) 3 and 18 years after planting compared to most other strains. 'August Red' and 'Starking' had larger TCSA and cumulative yield. 'Apex,' 'Improved Ryan Spur', 'Silverspur', 'Starkrimson', and 'Wellspur' were also among strains with high cumulative yields and yield efficiencies. 'Hardi-Brite Spur' and 'Red King Oregon Spur' had moderately high yields and small TCSAs, thus, high yield efficiencies. 'Atwood', 'Hardispur', 'Imperial', 'Improved Ryanred', 'Starkspur Supreme', and 'Topred' had low cumulative yields. 'Ace' and 'Improved Ryanred' had low yield efficiencies. 'Ace', 'Imperial', 'Red King Oregon Spur', 'Rose Red', 'Starking', and 'Wellspur' had heavier fruit, while fruit weight in 'August Red', 'Hardispur', and 'Starkrimson' was lighter than that in most other strains. 'Redspur' and 'Starkspur Supreme' had the largest length to diameter (L/D) ratios. 'Early Red One' had a similar red skin color rating as 'Rose Red.' The red skin color rating of 'Early Red One' was significantly higher than that of all other strains. 'Hi-Early', 'Improved Ryanred', 'Redspur', and 'Starking' had the poorest skin color ratings. 'Hardispur', 'Nured Royal', 'Silverspur', and 'Starkrimson' had high soluble solids concentrations (SSCs) at harvest and after storage. 'Early Red One', 'Imperial', 'Improved Ryan Spur', and 'Red King Oregon Spur' had lower SSCs at harvest and after storage. Fruit of 'Apex' and 'Redspur' had relatively high firmness at harvest, while 'Hardispur', 'Silverspur', 'Starkrimson', and 'Starkspur Supreme' had firm fruit at harvest and after storage. 'Hardi-Brite Spur' had the softest fruit after storage, and fruit from 'Rose Red' had a lower firmness than most other strains at harvest and after storage. Considering cumulative yield, yield efficiency, or some quality parameters, 'Apex', 'Classic Red', 'Improved Ryan Spur', 'Red King Oregon Spur', 'Silverspur', and 'Wellspur' had satisfactory overall performance. Strains are also suggested for planting depending on the market situation and the demand for a particular quality factor. 'Hardispur' and 'Sturdeespur' (Miller) are not recommended for planting under climatic conditions similar to those of this experiment.
\end{abstract}

The original 'Delicious' apple was discovered in 1879. Today, there are $>100$ strains (Fisher and Ketchie, 1989). 'Delicious' constitutes $37 \%$ of the apples grown in the world (Brueggen et al., 1988 ) and is the major apple cultivar grown in Idaho (Idaho Agricultural Statistics Service, 1991).

'Delicious' strains are selected for specific characteristics, primarily bearing habit (spur or standard type), yield, fruit color, and shape (Crassweller and Hollender, 1989; Crassweller et al., 1985; Fisher and Ketchie, 1981; Fisher et al., 1970; Ingle, 1972; Ketchie, 1984; Lord et al., 1980; Tukey and Ballard, 1969; Westwood, 1963, 1967; Westwood and Burkhart, 1968). Warrington et al. (1990) reported that spur-type strains had higher spur densities (spur/m of branch), spur leaf number, leaf areas per spur, leaf areas per leaf, and terminal bud diameters than those of standard-type strains. They also found a positive correlation between spur density and yield efficiency. Productivity of 'Delicious' strains has

Received for publication 3 Aug. 1992. Accepted for publication 1 Oct. 1993. The cost of publishing this paper was defrayed in part by the payment of page charges. Under postal regulations, this paper therefore must be hereby marked advertisement solely to indicate this fact.

${ }^{1}$ Fruit tree physiologist; to whom reprint requests should be addressed.

${ }^{2}$ Research associate.

${ }^{3}$ Postharvest physiologist.

${ }^{4}$ Present address: Van Buren County Cooperative Extension Service, 801 Hazen St., Suite A, Paw Paw, MI 49079-1075.

${ }^{5}$ Extension horticulturist.

${ }^{6}$ Horticulturist. been reported for Alabama (Dozier et al., 1984), Ohio (Ferree et al., 1975, 1982), Michigan, and West Virginia (Warrington et al., 1990). 'Starking' had the largest trunk cross-sectional area (TCSA) in Oregon (Westwood, 1967) and Michigan (Warrington et al., 1990). Lord et al. (1980), in a study of nine 'Delicious' strains, reported that cumulative yields per tree in most standard strains were higher than those in spur strains. Baugher et al. (1990) evaluated 34 strains and reported that 'Aomori', 'Classic Red', and 'Topred' had the largest trees, while 'Ace', 'Apex', 'Sturdeespur', and 'Topspur' had the smallest ones. In this report, 'Cascade Spur', 'Imperial', 'Oregon Spur', 'Silver Spur,' and 'Wayne Spur' were among the high-yielding strains, while 'Aomori', 'Bright 'n Early', 'Dixie Red', 'Rose Red', 'Scarlett Spur', 'Sharp Red', 'Triple Red', and 'Ultra Red' had low yield. Warrington et al. (1990) also reported low yield in 'Sharp Red' but high yield in 'Rose Red' in Michigan.

Different aspects of fruit quality, particularly fruit color, have been reported for various groups of 'Delicious' strains. Baugher et al. (1990) reported the highest color rating for 'Scarlett Spur' and 'Ultra Stripe' but least for 'Alred'. In this report, 'Ace' and 'Cascade Spur' were found to be superior for fruit color and productivity and 'Oregon Spur II' and 'Scarlett Spur' were found to be the best for fruit color and length to diameter (L/D) ratio. Crassweller et al. (1985) reported the highest color rating for 'Dixie Red' and 'Early Red One' but the least for 'Chelan Red', 'Classic Red', 'Redspur', and 'Rose Red' at the Georgia Mountain Experiment Station, Blairsville. 
In spite of the quantity of 'Delicious' apples produced and the extensive literature available on yield and growth habit of various strains of 'Delicious' from different apple growing regions, no comprehensive information is available concerning growth and yield and their relation to fruit quality after storage. Our objective was to evaluate the performance of 26 strains of 'Delicious' in relation to tree growth, yield, and fruit quality at harvest and after storage.

\section{Materials and Methods}

Twenty-six strains of 'Delicious' on M.7 rootstock were planted at the Univ. of Idaho Parma Research and Extension Center orchard in 1980 . Tree spacing was $3.65 \times 6.09 \mathrm{~m}$. Trees were trained as a modified central leader and pruned in February every year. The orchard was irrigated with an under-tree sprinkler system every 10 days during the growing season and weeds were controlled chemically. Fruit were thinned chemically with carbaryl (Sevin 50 WP; Rhone-Poulenc, Research Triangle, N.C.) 15 to 20 days after full bloom. Fruit were then hand thinned in early June if needed. Nitrogen was applied annually in early spring at the rates of 45 to $318 \mathrm{~g}$ actual $\mathrm{N}$ per tree, depending on tree age. No plant growth regulators were sprayed in this orchard to measure the natural length and diameter of the fruit. In general, all other cultural practices in this orchard were similar to those of commercial orchards in Idaho.

The experimental design was a completely randomized block design with six one-tree replications. Tree trunk circumference was measured in late February 1983 and 1991 and TCSA was calculated. Yields were recorded in 1986, 1990, 1991, and 1992.

General full bloom dates for the strains were 12 Apr. 1990, 25 Apr. 1991, and 8 Apr. 1992. No consistent difference was observed in full bloom date among different strains. Commercial harvest time for commercially grown strains was determined by taking periodic random samples and considering a combination of several maturity and quality factors, including fruit ground color (mostly red), seed color (brown), an iodine test $(\approx 2.6)$, and soluble solids concentration (SSC) $(>12 \%)$. Other researchers harvested fruit from all strains at the same time (Baugher et al., 1990; Crassweller and Hollender, 1989; Crassweller et al., 1985; Singha et al., 1991). Based on this information, fruit from all strains in this experiment were harvested at the same time (commercial harvest time) each year.

Two 12-fruit samples were picked randomly at commercial harvest time (2 Oct. 1990, 14 Oct. 1991, and 21 Sept. 1992, respectively) from each tree. Fruit were weighed and placed in perforated polyethylene bags. Fruit from one of these bags were tested for various fruit quality parameters at harvest. The second bag of fruit was stored in a regular atmosphere storage at $-1 \mathrm{C}$ with $\approx 90 \%$ relative humidity for 6 months and was tested after storage. Fruit weight was determined after storage. Fruit skin color was visually rated on a scale of 1 ( $<40 \%$ red) to $5(100 \%$ red) by one person at harvest and after storage. The color rating was based on a combination of percentage surface area with red color and intensity of red color. Fruit length and diameter were measured at harvest time with a digital caliper (Starrett No. 722, Sears) and L/ $\mathrm{D}$ ratio was computed.

Fruit firmness was measured at harvest and after storage on three peeled sides of each fruit by a Univ. of California, Davis, penetrometer (McCormick Fruit Tech., Yakima, Washington), and fruit were then cut tangentially. The stem-end half of the fruit at harvest was dipped in iodine solution, and the starch degradation pattern (SDP) for each fruit was determined by comparing devel- oped patterns with the standard SDP developed by Cascade Analytical (Wenatchee, Wash.). In this procedure, a fruit with the lowest SDP (highest possible starch content) is rated as 1.2 and one with the highest possible SDP is rated as 6.0 (lowest possible starch content). The calyx-end half of each fruit was juiced (Acme Juicerator, New Hartford, Conn.), three to four drops of juice were placed on a hand-held temperature compensated refractometer (Atago N, Tokyo), and SSC was measured.

Analyses of variance (ANOVAs) were computed for TCSA in 1983 and 1991, yield for 1986, 1990, 1991, 1992, and cumulative yield over 4 years. Yield efficiency was calculated as cumulative yield in 1990-92/TCSA in 1991. ANOVAs were also computed for yield efficiency and for all fruit quality factors at harvest and after storage for 1990, 1991, 1992, and for the average of these three years using SAS's (Cary, N.C.) program. Least significant differences (LSDS) at $P=0.05$ were computed to compare strain means. The color ratings and percentage weight loss values were transformed to arcsin values. The ANOVA and LSD for original ratings, percentage weight loss, and transformed values were identical because the original color ratings and percentage weight loss had normal distributions. Therefore, the original fruit color ratings and percentage weight loss rather than the transformed values are reported.

\section{Results and Discussion}

Growth. Strains were categorized as standard or spur based on their bearing habit according to Tukey and Ballard (1969) and Warrington et al. (1990). In general, standard strains had a larger TCSA than spur strains in 1991, 11 years after planting (Table 1, Fig. 1). Most strains in Idaho had a noticeably larger TCSA (Table 1) than those grown in West Virginia (Baugher et al., 1990). TCSA of 'Starking' was larger than all other strains except 'August Red' 3 years after planting in 1983 and except 'Sharp Red' in 1991 (Table 1), results that agree with previous reports (Warrington et al., 1990; Westwood, 1967). 'August Red', 'Rose Red', and 'Sharp Red' were also among the strains with large TCSA in 1983 and 1991 (Table 1).

In 1991, 'Atwood', 'Hardi-Brite Spur', 'Hardispur', 'Red King Oregon Spur', Spured Royal', and 'Sturdeespur' had the smallest trees. These results generally agree with Baugher et al. (1990) in West Virginia, Warrington et al. (1990) in Michigan and West Virginia, and Lord et al. (1980) in Massachusetts, although the strains tested among these evaluation sites were not all identical.

The TCSA of 'Ace' was not significantly different than most other strains 3 years after planting either in Idaho (Table 1) or West Virginia (Baugher et al., 1990). However, by 1991, 'Ace' trees had grown faster and TCSA in 'Ace' trees was significantly larger than that of 'Hardispur', 'Improved Ryan Spur', 'Red King Oregon Spur', 'Spured Royal', 'Starkspur', 'Sturdeespur', and 'Wellspur' (Table 1). The opposite result was observed in the West Virginia experiment (Baugher et al., 1990), where 'Ace' had a smaller TCSA than these strains 7 years after planting. This result indicates that 'Ace's growth performance may vary with environment, and this fact should be kept in mind when planting 'Ace' under different climatic conditions.

Yield and yield efficiency. Yields of all strains in 1990 were more than those in 1986 (Table 1). Yields of most strains in 1991 were lower than those of 1990 because low temperatures in December 1990 to January 1991 reduced fruit production in the Pacific Northwest. This reduction seemed to be less severe in standard than in spur strains (Table 1). Severity of biennial bearing in spur strains could also contribute to the 1991 yield reduction. 
Table 1. Growth, yield, and yield efficiency of 'Delicious' strains ${ }^{\mathrm{z}}$.

\begin{tabular}{|c|c|c|c|c|c|c|c|c|c|}
\hline \multirow[b]{3}{*}{ Strain } & \multirow{3}{*}{$\begin{array}{c}\text { Growth } \\
\text { type }^{\mathrm{y}}\end{array}$} & \multirow{2}{*}{\multicolumn{2}{|c|}{$\begin{array}{c}\text { Trunk } \\
\text { cross-sectional } \\
\text { area }\left(\mathrm{cm}^{2}\right)\end{array}$}} & \multirow[b]{3}{*}{1986} & \multicolumn{3}{|c|}{$\begin{array}{c}\text { Yield } \\
\text { (kg/tree) }\end{array}$} & \multirow{3}{*}{$\begin{array}{c}\text { 4-year } \\
\text { cumulative } \\
\text { yield }^{\mathrm{x}}\end{array}$} & \multirow{3}{*}{$\begin{array}{c}\text { Cumulative } \\
\text { yield } \\
\text { efficiency } \\
\left(\mathrm{kg} \cdot \mathrm{cm}^{-2}\right)\end{array}$} \\
\hline & & & & & \multirow[b]{2}{*}{1990} & \multirow[b]{2}{*}{1991} & \multirow[b]{2}{*}{1992} & & \\
\hline & & 1983 & 1991 & & & & & & \\
\hline$\overline{\text { Ace }}$ & $\mathrm{Sp}$ & 22.5 & 136.0 & 35.8 & 61.3 & 24.3 & 47.4 & 168.7 & 1.0 \\
\hline Apex & $\mathrm{Sp}$ & 23.3 & 122.8 & 39.0 & 103.1 & 22.2 & 59.9 & 224.3 & 1.6 \\
\hline Atwood & $\mathrm{Sp}$ & 18.9 & 95.7 & 31.9 & 60.9 & 19.4 & 47.4 & 159.6 & 1.3 \\
\hline August Red & St & 29.9 & 155.5 & 39.6 & 82.9 & 69.9 & 41.8 & 234.2 & 1.2 \\
\hline Classic Red & St & 21.9 & 141.5 & 30.4 & 90.4 & 51.8 & 38.5 & 211.1 & 1.3 \\
\hline Early Red One & St & 21.5 & 116.1 & 42.0 & 79.1 & 44.6 & 36.3 & 201.9 & 1.4 \\
\hline Hardi-Brite Spur & $\mathrm{Sp}$ & 16.2 & 76.1 & 51.6 & 65.0 & 45.4 & 41.1 & 203.1 & 2.0 \\
\hline Hardispur & $\mathrm{Sp}$ & 14.4 & 75.1 & 24.2 & 62.2 & 6.2 & 35.7 & 128.3 & 1.5 \\
\hline Hi-Early & St & 20.4 & 138.9 & 32.9 & 55.9 & 62.1 & 33.5 & 184.4 & 1.1 \\
\hline Imperial & St & 20.4 & 122.3 & 30.5 & 69.1 & 34.2 & 23.1 & 156.9 & 1.1 \\
\hline Improved Ryanred & St & 18.4 & 122.7 & 26.8 & 56.5 & 35.4 & 13.6 & 132.2 & 0.9 \\
\hline Improved Ryan Spur & $\mathrm{Sp}$ & 24.5 & 105.4 & 45.6 & 100.4 & 33.0 & 69.7 & 248.6 & 1.9 \\
\hline Nured Royal & St & 22.4 & 133.0 & 24.4 & 74.3 & 49.5 & 36.8 & 185.0 & 1.2 \\
\hline Red King Oregon Spur & $\mathrm{Sp}$ & 19.2 & 98.7 & 36.0 & 88.7 & 38.1 & 45.2 & 208.0 & 1.8 \\
\hline Redspur & $\mathrm{Sp}$ & 20.1 & 111.2 & 40.0 & 89.8 & 12.6 & 61.8 & 204.2 & 1.5 \\
\hline Rose Red & St & 23.0 & 149.7 & 32.1 & 75.9 & 47.7 & 39.3 & 195.0 & 1.1 \\
\hline Sharp Red & St & 25.3 & 165.4 & 30.3 & 61.0 & 73.5 & 32.8 & 197.6 & 1.0 \\
\hline Silverspur & $\mathrm{Sp}$ & 24.4 & 102.5 & 46.5 & 99.5 & 9.9 & 69.8 & 225.7 & 1.7 \\
\hline Spured Royal & $\mathrm{Sp}$ & 22.2 & 95.0 & 35.8 & 68.0 & 27.0 & 54.6 & 185.3 & 1.7 \\
\hline Starking (Mood) & $\mathrm{St}$ & 35.0 & 182.8 & 51.9 & 97.6 & 101.2 & 19.0 & 269.6 & 1.2 \\
\hline Starkrimson (Bisbee) & $\mathrm{Sp}$ & 25.6 & 108.0 & 48.2 & 79.7 & 21.1 & 72.3 & 221.3 & 1.6 \\
\hline Starkspur Supreme & $\mathrm{Sp}$ & 21.5 & 103.1 & 21.5 & 66.0 & 35.5 & 32.9 & 155.8 & 1.4 \\
\hline Starkspur Ultrared & $\mathrm{Sp}$ & 20.9 & 121.3 & 17.8 & 83.0 & 38.4 & 23.1 & 162.3 & 1.2 \\
\hline Sturdeespur (Miller) & $\mathrm{Sp}$ & 18.9 & 99.8 & 35.0 & 64.5 & 11.7 & 51.0 & 162.1 & 1.3 \\
\hline Topred & $\mathrm{St}$ & 18.8 & 122.1 & 25.3 & 48.2 & 47.9 & 34.0 & 155.4 & 1.1 \\
\hline Wellspur & $\mathrm{Sp}$ & 21.2 & 109.8 & 45.2 & 84.5 & 49.0 & 45.4 & 224.1 & 1.6 \\
\hline $\operatorname{LSD}(P<0.05)$ & & 6.1 & 25.4 & 20.5 & 32.6 & 25.1 & 26.8 & 60.8 & 0.4 \\
\hline
\end{tabular}

${ }^{\mathrm{z}}$ Values of each year are means of six replications of one-tree plots.

${ }^{\mathrm{y}}$ Growth type: $\mathrm{Sp}=$ spur; $\mathrm{St}=$ standard.

${ }^{x}$ Cumulative yield over 1986, 1990, 1991, and 1992.

${ }^{\text {w1} 1990-92 ~ C u m u l a t i v e ~ y i e l d / 1991 ~ t r u n k ~ c r o s s-s e c t i o n a l ~ a r e a . ~}$

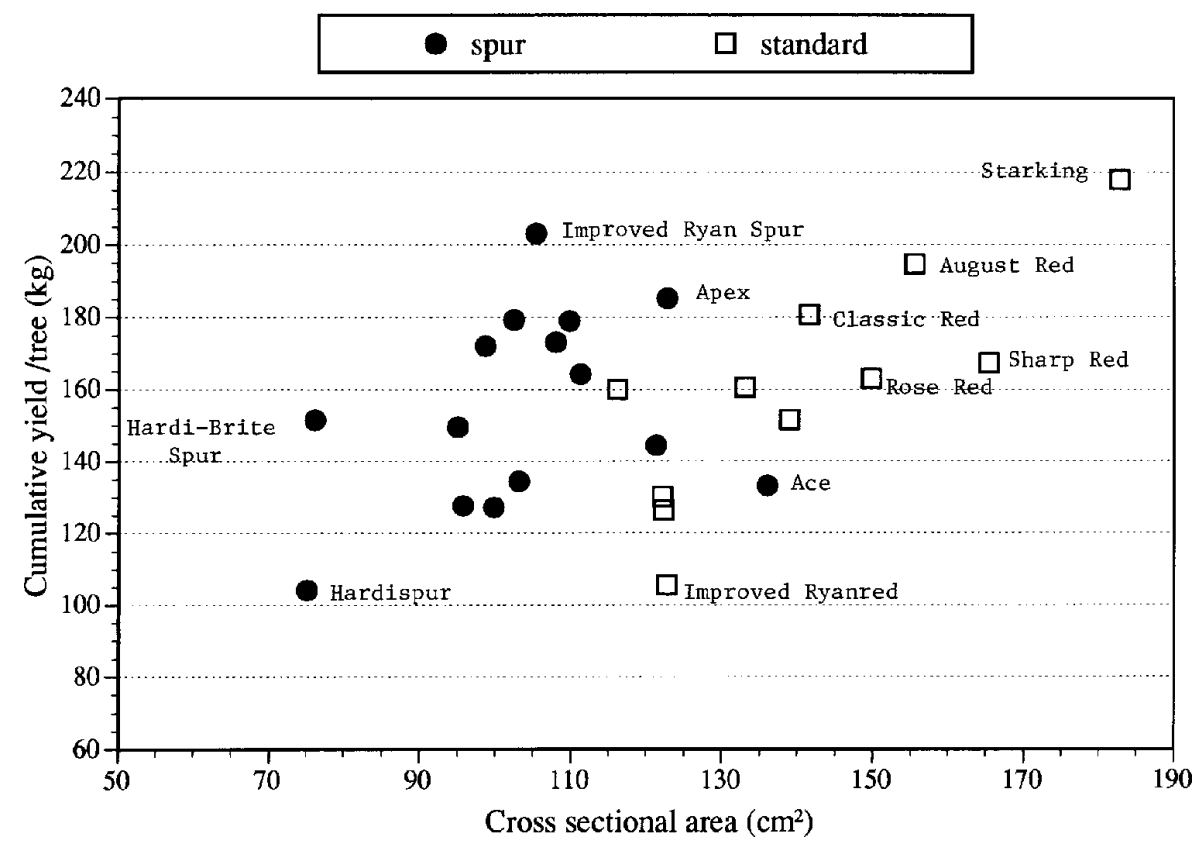

Fig. 1. Scatter diagram of trunk cross-sectional area and 3-year (1990-92) cumulative yield separated by growth habit. 
Reduced yields of 'Apex', 'Hardispur', Improved Ryan Spur', 'Redspur', 'Silverspur', and 'Starkrimson' were more drastic than in other strains (Table 1). Increase or decrease of yield in 1992 compared to yield in 1991 in most strains is likely to be a reflection of their biennial bearing habit.

There was no particular pattern along the line between spur and standard types for cumulative yield (Table 1). Generally, small spur-type trees yielded equally to small standard trees (Table 1, Fig. 1). The 4-year cumulative yields of 'Apex', 'August Red', 'Classic Red', 'Improved Ryan Spur', 'Silver Spur', 'Starking', 'Starkrimson', and 'Wellspur' were the highest. 'Hardispur' and 'Improved Ryanred' had the lowest cumulative yields (Table 1).

In general, yield efficiencies of spur strains were greater than those of standard types (Table 1 and Fig. 2). 'Apex', 'Hardi-Brite Spur', 'Improved Ryan Spur', 'Red King Oregon Spur', 'Silverspur', 'Spured Royal', 'Starkrimson', and 'Wellspur' showed high cumulative yield efficiencies. Slow growth in TCSA between 1983 and 1991 and higher yield efficiency in strains such as 'Hardi-Brite Spur', 'Improved Ryan Spur', 'Red King Oregon Spur', and 'Silverspur' (Table 1) suggests that these strains could be planted at a higher density, leading to a higher yield per hectare. 'Ace', 'Imperial', 'Improved Ryanred', and 'Sharp Red' had low yield efficiencies (Table 1). The high yield efficiencies of 'Apex', 'Hardi-Brite Spur', and 'Silverspur' and low yield efficiencies of 'Improved Ryan Red', 'Sharp Red', and 'Topred' agree with reports from West Virginia (Baugher et al., 1990). In contrast to our results, 'Ace' showed a higher yield efficiency in Michigan (Warrington et al., 1990) and West Virginia (Baugher et al., 1990). This underscores the need to select strains that are adapted to individual growing areas.

'Early Red One' behaved like a spur type because of its relatively small TCSA, while 'Starkspur Ultrared' and 'Ace' behaved like standard types due to their large TCSAs (Table 1 and Fig. 1).

Fruit weight. 'Ace', 'Imperial', 'Red King Oregon Spur', 'Rose Red', 'Starking', and 'Wellspur' strains had heavier fruit than most other strains and were significantly heavier than 'August Red', 'Hardi-Brite Spur', 'Hardispur', 'Redspur', and 'Starkrimson', (Table 2). 'Imperial', 'Red King Oregon Spur', and 'Rose Red' also produced heavy fruit in Michigan (Warrington et al., 1990). Fruit weight of 'Wellspur' in Michigan was lighter (Warrington et al., 1990), while it was heavier than most other strains in our evaluation (Table 2). 'Starking' trees produced heavy fruit (Table 2) and high cumulative yields (Table 1), and 'Improved Ryan Spur', 'Red King Oregon Spur', 'Silverspur', and 'Wellspur' produced heavy fruit along with high cumulative yields and yield efficiencies (Tables 1 and 2, Fig. 2). Fruit weight in 'Rose Red' was heavy but yield efficiency was low. On the other hand, 'HardiBrite Spur' fruit were light-weight, but yield efficiency was high (Fig. 2). Fruit weight in 'August Red' and 'Starkrimson' was light (Table 2), which could be due in part to their high cumulative yields (Table 1). Fruit from 'Hardispur' trees were lighter than other strains (Table 2), in spite of the low cumulative yield in these trees (Table 1). This result suggests that crop load alone may not necessarily alter fruit weight, and the genetic makeup of the strains plays an important role in fruit weight.

Fruit shape. Spur strains had higher L/D ratios than standard types. However, 'Imperial' behaved like a spur type with its high L/D ratio, which was among the top five strains (Table 2). 'Starkspur Supreme' had a significantly larger L/D ratio than all other strains, followed by 'Redspur' (Table 2). 'Redspur' is a common commercial strain grown in the Pacific Northwest. 'Rose Red' and 'Improved Ryanred' fruit had a lower L/D ratio than several other strains (Table 2). A high L/D ratio in 'Starkspur Supreme' was also reported in West Virginia (Baugher et al., 1990). Fruit L/D ratio of 'Starking' (standard) was similar to that of 'Starkrimson' (spur). This finding differs from an earlier report by Westwood (1963), where 'Starkrimson' was more elongated than 'Starking'. This difference could be due to climatic differences (Westwood and Burkhart, 1968) between western Oregon and southwestern Idaho. 'Imperial' behaved like a spur type with its high L/D ratio (Table 2).

Fisher and Ketchie (1981) reported that fruit of 'Red King Oregon Spur' had the lowest L/D ratio compared to those of 'Redspur', 'Starking', 'Starkrimson', 'Topred', and 'Wellspur'. This is different from our results, where 'Red King Oregon Spur' had a similar L/D ratio to the above mentioned strains (Table 2).

Fruit color. Fruit of 'Early Red One' had a similar red skin color

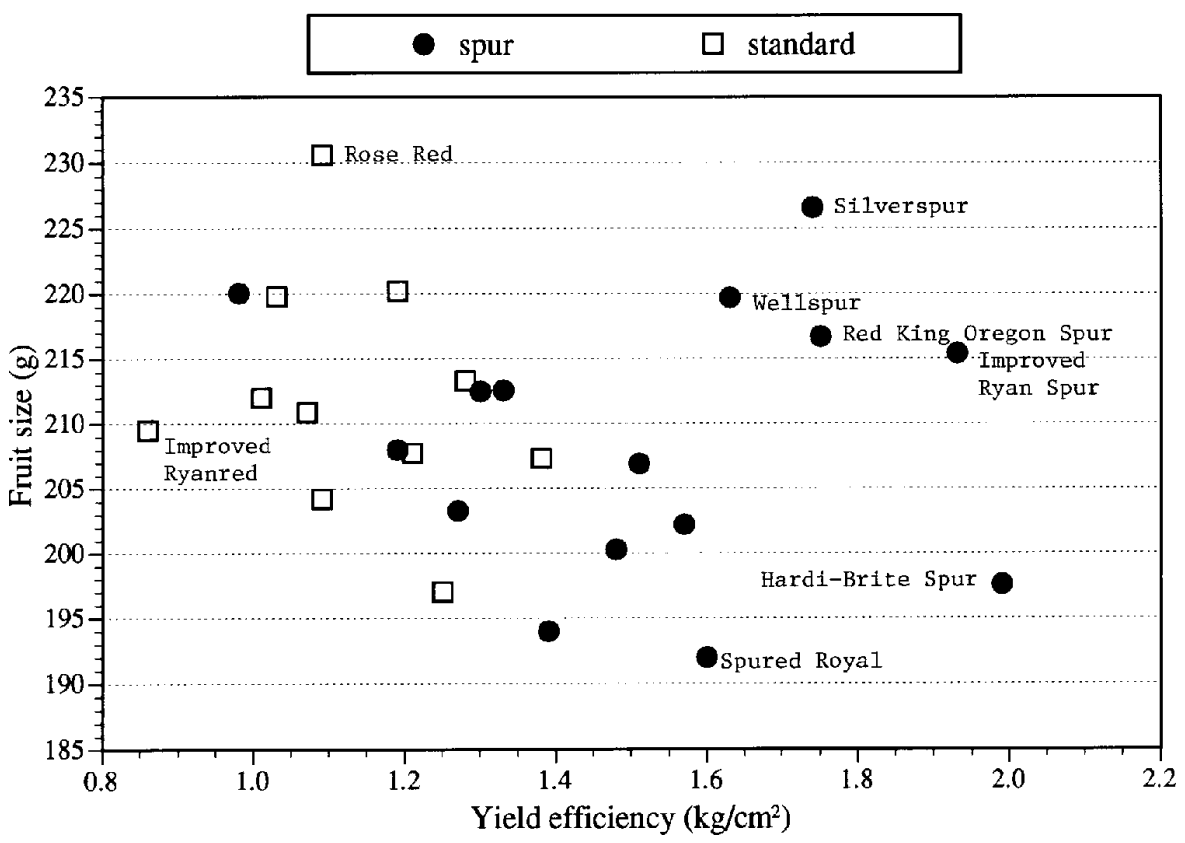

Fig. 2. Scatter diagram of yield efficiency and fruit size separated by growth habit. 
Table 2. Fruit color pattern and average fruit weight, length to diameter (L/D) ratio, skin red color rating, and starch degradation pattern of 'Delicious' strains at harvest over $1990-92^{\mathrm{z}}$.

\begin{tabular}{|c|c|c|c|c|c|}
\hline Strain & $\begin{array}{c}\text { Color } \\
\text { pattern }^{\mathrm{y}}\end{array}$ & $\begin{array}{l}\text { Wt } \\
(\mathrm{g})\end{array}$ & $\begin{array}{l}\mathrm{L} / \mathrm{D} \\
\text { ratio }\end{array}$ & Color $^{x}$ & $\mathrm{SDP}^{\mathrm{w}}$ \\
\hline$\overline{\text { Ace }}$ & $\mathrm{S}, \mathrm{B}$ & 220.1 & 0.995 & 3.73 & 3.26 \\
\hline Apex & S, B & 206.9 & 0.994 & 3.49 & 2.93 \\
\hline Atwood & $\mathrm{B}$ & 212.6 & 0.982 & 3.31 & 3.17 \\
\hline August Red & $\mathrm{B}$ & 197.0 & 0.970 & 3.76 & 3.01 \\
\hline Classic Red & $\mathrm{S}$ & 213.3 & 0.981 & 3.53 & 2.66 \\
\hline Early Red One & $\mathrm{S}$ & 207.3 & 0.984 & 4.27 & 3.44 \\
\hline Hardi-Brite Spur & B & 197.6 & 0.997 & 3.49 & 3.24 \\
\hline Hardispur & $\mathrm{B}$ & 194.0 & 0.987 & 3.26 & 2.72 \\
\hline Hi-Early & $\mathrm{S}$ & 204.2 & 0.979 & 2.93 & 2.96 \\
\hline Imperial & $\mathrm{B}$ & 219.8 & 0.995 & 3.59 & 3.10 \\
\hline Improved Ryanred & $S, B$ & 209.5 & 0.967 & 3.11 & 3.16 \\
\hline Improved Ryan Spur & S, B & 215.4 & 0.981 & 3.53 & 2.95 \\
\hline Nured Royal & $\mathrm{B}$ & 207.7 & 0.987 & 3.70 & 3.13 \\
\hline Red King Oregon Spur & S,B & 226.6 & 0.989 & 3.63 & 3.24 \\
\hline Redspur & $\mathrm{B}$ & 200.3 & 1.000 & 2.91 & 2.96 \\
\hline Rose Red & B & 230.6 & 0.969 & 3.94 & 2.90 \\
\hline Sharp Red & $\mathrm{S}$ & 212.0 & 0.987 & 3.59 & 3.23 \\
\hline Silverspur & S, B & 216.7 & 0.991 & 3.33 & 2.68 \\
\hline Spured Royal & $\mathrm{B}$ & 202.2 & 0.981 & 3.29 & 3.13 \\
\hline Starking (Mood) & $\mathrm{S}$ & 220.2 & 0.988 & 2.26 & 3.14 \\
\hline Starkrimson (Bisbee) & $\mathrm{B}$ & 192.0 & 0.986 & 3.56 & 3.20 \\
\hline Starkspur Supreme & B & 212.5 & 1.023 & 3.56 & 2.98 \\
\hline Starkspur Ultrared & S,B & 208.0 & 0.981 & 3.85 & 3.17 \\
\hline Sturdeespur (Miller) & S,B & 203.3 & 0.986 & 3.19 & 3.29 \\
\hline Topred & $\mathrm{S}$ & 210.9 & 0.986 & 3.28 & 3.30 \\
\hline Wellspur & $\mathrm{B}$ & 219.7 & 0.998 & 3.39 & 2.49 \\
\hline $\operatorname{LSD}(P<0.05)$ & & 18.2 & 0.019 & 0.40 & 0.36 \\
\hline
\end{tabular}

${ }^{\mathrm{Z}}$ Each value is the 3-year mean of 1990, 1991, and 1992 with six one-tree replications each year.

y Color pattern: $\mathrm{S}=$ striped; $\mathrm{B}=$ blushed; $\mathrm{S}, \mathrm{B}=$ striped early turning to blush at harvest.

${ }^{\mathrm{x}}$ Color rating scale: 1 is $<40 \%$ red progressively to $5=100 \%$ red.

${ }^{\mathrm{w}} \mathrm{SDP}=$ starch degradation pattern. Highest $\mathrm{SDP}=6.0 ;$ lowest $=1.2$.

rating as those of 'Rose Red', but the color rating was significantly higher than that of all other strains (Table 2). 'Ace', 'August Red', and 'Starkspur Ultra Red' had high red skin color ratings, while 'Hi-Early', 'Improved Ryanred', 'Redspur', and 'Starking' had the poorest skin color ratings among all strains (Table 2). The higher red skin color rating in 'Ace', 'Early Red One', and 'Starkspur Ultrared' and poor color rating in 'Redspur' is consistent with the results in Georgia, where red skin color of these strains was measured based on lightness and red/yellow color ratio (Crassweller et al., 1985). 'Ace' and 'Starkspur Ultrared' also had high color ratings in West Virginia (Baugher et al., 1990). However, 'Rose Red' had the poorest skin color next to 'Redspur' among 18 strains in Georgia (Crassweller et al., 1985), of which 11 were the same as those used in this experiment.

A color evaluation for 32 strains gave the following results (unpublished data): the top five were 'Topred', 'Starkrimson', 'Red Prince', 'Watsonville', and 'Chelan Red' and the bottom five were 'Earlired', 'Starking', 'Paynter', 'Richared', and 'Woodspur'. Although all of the tested strains in our experiment were not the same as those above, we also found that 'Starking' had the poorest color among all strains. It is noteworthy that the strain with highest red color ('Early Red One') and that with poorest red color ('Starking') are both striped type (Table 2). In addition, stripe and blush strains can be seen among the top highly colored and bottom poorly colored strains (Table 2). Therefore, it is not possible to draw a line between stripe vs. blush strains for fruit color.
SDP. SDP was statistically similar in most strains, with 'Early Red One' ranking the highest (Table 2). The uniformity in SDP suggests that most of the strains were in a similar stage of maturity when they were harvested. Fruit of 'Classic Red', 'Hardispur', 'Silverspur', and 'Wellspur' had relatively lower SDP than other strains (Table 2). 'Silverspur' and 'Wellspur' also had low SDP in West Virginia (Baugher et al. 1990). A significant negative correlation existed between fruit SDP over all strains at harvest and SSC after storage $(r=-0.52)$.

SSC. Some of the strains with low yield such as 'Hardispur' had high SSC at harvest and after storage (Table 3). 'Apex', 'Starking', and 'Wellspur', which had high yields, showed lower SSC at harvest (Table 3). Although the negative correlation coefficient between yield and harvest SSC over all strains was significant ( $r$ $=-0.50)$, this relationship did not exist for all strains. For example, 'August Red', 'Silverspur', and 'Starkrimson' trees produced relatively high cumulative yields (Table 1) and fruit with relatively high SSC at harvest and after storage (Table 3). 'Imperial' was among strains with high SSC in West Virginia (Baugher et al., 1990), while this strain was in the group with low SSC in our study (Table 3).

Firmness. A significant correlation existed between fruit firmness at harvest and after storage $(r=0.72)$. 'Apex', 'Hardispur', 'Redspur', 'Silverspur', 'Starkrimson', and 'Starkspur Supreme' were among the strains with high fruit firmness at harvest. 'Apex' also had high firmness but 'Redspur' had the lowest firmness in 
Table 3. Average fruit soluble solids concentrations, firmness, and weight loss of 'Delicious' strains.

\begin{tabular}{|c|c|c|c|c|c|c|}
\hline Strain & $\begin{array}{c}\text { Harvest } \\
\text { soluble } \\
\text { solids }{ }^{\mathrm{z}} \\
(\%)\end{array}$ & $\begin{array}{c}\text { Storage } \\
\text { soluble } \\
\text { solids }^{\mathrm{y}} \\
(\%)\end{array}$ & $\begin{array}{l}\text { Harvest } \\
\text { firmness } \\
\text { (N) }\end{array}$ & $\begin{array}{l}\text { Storage } \\
\text { firmness } \\
\text { (N) }\end{array}$ & $\begin{array}{l}\text { Loss of } \\
\text { firmness } \\
\text { (N) }\end{array}$ & $\begin{array}{l}\text { Fruit } \\
\text { wt } \\
\operatorname{loss^{y}} \\
(\%)\end{array}$ \\
\hline$\overline{\text { Ace }}$ & 13.1 & 13.3 & 77.0 & 58.7 & 18.3 & 3.6 \\
\hline Apex & 12.5 & 13.0 & 80.3 & 62.1 & 18.2 & 3.5 \\
\hline Atwood & 13.1 & 13.4 & 77.9 & 60.0 & 18.0 & 3.5 \\
\hline August Red & 13.3 & 13.6 & 77.8 & 56.1 & 21.7 & 4.3 \\
\hline Classic Red & 12.9 & 13.4 & 79.7 & 62.8 & 16.9 & 4.8 \\
\hline Early Red One & 12.9 & 12.8 & 75.7 & 56.0 & 19.7 & 3.6 \\
\hline Hardi-Brite Spur & 13.0 & 13.0 & 76.3 & 54.4 & 21.8 & 3.0 \\
\hline Hardispur & 13.5 & 13.5 & 80.0 & 64.7 & 15.4 & 3.6 \\
\hline Hi-Early & 13.1 & 13.6 & 78.7 & 59.1 & 19.6 & 3.7 \\
\hline Imperial & 12.8 & 12.8 & 74.8 & 60.2 & 14.6 & 3.4 \\
\hline Improved Ryanred & 12.6 & 13.4 & 76.1 & 59.4 & 16.7 & 3.7 \\
\hline Improved Ryan Spur & 12.9 & 12.7 & 77.6 & 59.9 & 17.7 & 3.5 \\
\hline Nured Royal & 13.4 & 13.6 & 77.6 & 60.4 & 17.2 & 3.4 \\
\hline Red King Oregon Spur & 12.9 & 12.9 & 76.4 & 57.5 & 18.9 & 3.1 \\
\hline Redspur & 12.7 & 13.2 & 79.9 & 61.8 & 18.1 & 4.0 \\
\hline Rose Red & 13.5 & 13.3 & 73.9 & 56.0 & 18.0 & 3.3 \\
\hline Sharp Red & 13.2 & 13.2 & 78.5 & 59.1 & 19.4 & 3.5 \\
\hline Silverspur & 13.2 & 13.6 & 80.5 & 66.5 & 14.0 & 4.7 \\
\hline Spured Royal & 12.8 & 13.4 & 77.6 & 65.1 & 12.6 & 3.5 \\
\hline Starking (Mood) & 12.8 & 13.3 & 76.4 & 56.0 & 20.4 & 3.2 \\
\hline Starkrimson (Bisbee) & 13.5 & 13.4 & 80.3 & 66.6 & 13.7 & 3.6 \\
\hline Starkspur Supreme & 13.0 & 13.3 & 80.1 & 67.6 & 12.5 & 3.3 \\
\hline Starkspur Ultrared & 13.0 & 13.2 & 77.5 & 57.4 & 20.0 & 3.6 \\
\hline Sturdeespur (Miller) & 13.4 & 13.5 & 77.8 & 61.1 & 16.7 & 3.8 \\
\hline Topred & 13.4 & 13.2 & 77.1 & 58.4 & 18.7 & 3.7 \\
\hline Wellspur & 12.6 & 13.0 & 76.7 & 56.9 & 19.8 & 3.2 \\
\hline $\operatorname{LSD}(P<0.05)$ & 0.7 & 0.7 & 2.8 & 3.4 & 3.4 & 1.0 \\
\hline
\end{tabular}

${ }^{\mathrm{z}}$ Each value is the 3-year mean of 1990, 1991, and 1992, with six one-tree replications

yEach value is the 2-year mean of 1990 and 1991, with six one-tree replications.

West Virginia (Baugher et al., 1990). 'Hardispur', 'Silverspur', 'Starkrimson', and 'Starkspur Supreme' had firmer fruit than most other strains at harvest and after storage (Table 3). Similar to our results, Crassweller and Hollender (1989) reported that fruit of 'Silverspur' were significantly firmer than those of 'Ace' at harvest; however, contrary to our findings, firmness differences between these strains were not significant after a shorter storage (74 days) in Pennsylvania. 'Hardi-Brite Spur' had the softest fruit after storage and fruit from 'Rose Red' had lower firmness than most other strains at harvest and after storage (Table 3). 'August Red', 'Hardi-Brite Spur', and 'Starking' had the greatest loss of firmness after storage while 'Silverspur', 'Spured Royal', 'Starkrimson', and 'Starkspur Supreme' had the least loss of firmness after storage (Table 3).

Weight loss. Fruit weight loss was highest in 'August Red', 'Classic Red', 'Redspur', and 'Silverspur', while it was lowest in 'Hardi-Brite Spur' and 'Red King Oregon Spur' (Table 3). Weight loss had a significant correlation with fruit SSC after storage $(r=$ 0.50 ).

Overall growth, yield, and quality performance. It is difficult to select a superior strain, as the importance of each characteristic may vary among different growing regions and even among growers, depending on the marketing situation of each. For example, if high production per tree is the major factor for a particular market, 'Apex', 'August Red', 'Classic Red', 'Improved Ryan Spur', 'Silverspur', 'Starking', 'Starkrimson', and 'Wellspur' would be the strains of choice. If high yield efficiency is the main objective of production, 'Hardi-Brite Spur', 'Improved Ryan Spur', 'Red King Oregon Spur', 'Silverspur', 'Spured Royal', and 'Wellspur' can be chosen (Table 1, Fig. 2). If heavy fruit along with high yield per tree and yield efficiency is the production goal, 'Improved Ryan Spur', 'Red King Oregon Spur', 'Silver Spur', and 'Wellspur' can be chosen. However, if high fruit color for early market is the primary goal of production, 'Early Red One' and 'Rose Red' are good choices. These two strains should only be considered for early harvest and fresh market because of their soft fruit or loss of firmness in storage (Table 3). 'Rose Red', in addition to its high red skin color, has heavy fruit (Table 2). However, since L/D ratio of 'Rose Red' fruit is very low, the application of plant growth regulators to improve the L/D ratio in this strain is advisable. We observed severe fruit russeting in 'Rose Red' and 'Improved Ryanred' in 1992, which is an undesirable feature of these strains in some years. No fruit russeting was found in any of the other strains. 'Starkrimson' is a good choice as a high yielding strain with good fruit color, firmness, and SSC, but this fruit has light weight. 'Starkspur Supreme' trees did not produce high yields, however, fruit of this strain was firmer at harvest and after storage and had the least firmness loss during storage. Fruit of this strain may have higher levels of fruit $\mathrm{Ca}$, contributing to its high firmness (Fallahi et al., 1985). 'Starkspur Supreme' also had a significantly higher L/D ratio than all other strains. Some highyielding strains also had one or more desirable quality factors. For example, 'Apex', 'Classic Red', and 'Silverspur' had high fruit firmness at harvest and after storage. 'Red King Oregon Spur' had 
moderately high yield and heavy fruit with a relatively high red skin color rating (Tables 1 and 2). 'Silverspur' had heavy fruit, with low loss of firmness after storage. 'Wellspur' had high cumulative yield, yield efficiency, heavy fruit and a high L/D ratio (Tables 1 and 2). 'Improved Ryan Spur' had high cumulative yield and yield efficiency, along with heavy fruit and relatively good color (Tables 1 and 2). Thus, 'Apex', 'Classic Red', 'Improved Ryan Spur', 'Red King Oregon Spur', 'Silverspur', and 'Wellspur' are considered to be strains with satisfactory overall performance. The high overall acceptability of 'Red King Oregon Spur' and 'Silverspur' were also reported by Crassweller and Hollender (1989).

'Redspur', which is one of the major strains grown in Idaho, had relatively small fruit, poor color, and high weight loss after storage. Fruit of this strain, however, were among the firmest at harvest and after storage. 'Redspur' is usually the last 'Delicious' strain harvested to gain better color, and the fruit are often used for longterm storage because of their relatively high firmness. Because of the tendency for poor color development, time and amount of $\mathrm{N}$ application is very critical and should be given careful attention (unpublished data).

The high yield efficiencies and relatively small TCSAs of 'Hardi-Brite Spur', 'Improved Ryan Spur', 'Red King Oregon Spur', 'Silverspur', 'Spured Royal', and 'Wellspur' (Table 1) suggest that yield per hectare could perhaps be increased by planting these strains at a closer spacing than that used in this experiment. 'Starking' has high cumulative yields. It is also generally agreed that 'Starking' has an excellent flavor, as judged by consumer preference (Crassweller and Hollender, 1989) and as measured biochemically in our previous report (Fellman et al., 1990). However, the poor skin color of this strain presents a major disadvantage. Therefore, 'Starking' deserves to be considered and marketed as a specialty apple.

'Hardispur' and 'Sturdeespur' had poor overall performance; they had low yield and/or small fruit and poor skin color. These strains are not recommended for climatic conditions similar to those of this experiment.

\section{Literature Cited}

Baugher, T.A., S. Singha, E.C. Townsend, and M. Ingle. 1990. Growth, yield and fruit quality of 'Delicious' apple strains. West Virginia Agr. and For. Expt. Sta., Morgantown. Bul. 702.

Brueggen, J.J., C. Botkin, R. Lewis, C. Mace, and A. Wilcox. 1988. West Virginia fruit tree survey-1987. West Virginia and U.S. Depts. of Agr. Crassweller, R.M. and R.A. Hollender. 1989. Consumer evaluations of
'Delicious' apple strains. Fruit Var. J. 43:139-142.

Crassweller, R.M., J. Walker, and R.L. Shewfelt. 1985. Color evaluation of seventeen strains of 'Delicious.' Fruit Var. J. 39:21-24.

Dozier, W.A., Jr., J.W. Knowles, W.A. Griffey, H.E. Burgess, E.L. Mayton, A.A. Powell, and J.A. McGuire. 1984. Evaluation of five nonspur strains of Red Delicious apples in central Alabama. Alabama Agr. Expt. Sta., Auburn. Bul. 557.

Fallahi, E., D.G. Richardson, M.N. Westwood, and M.H. Chaplin. 1985. Relationships among mineral nutrition, ethylene, and postharvest physiology in apples on six rootstocks. Scientia Hort. 25:163-175.

Fellman, J.K., E. Fallahi, and J.P. Mattheis. 1991. Flavor of red 'Delicious' strains. Proc. Washington Tree Fruit Postharvest Conf. p. 30-33.

Ferree, D.C., C.A. Morrison, and L.C. Shew. 1975. Red Delicious apples which strain is best? Ohio Rpt. 60:19-22.

Ferree, D.C., J.C. Schmid, and C.A. Morrison. 1982. An evaluation over 16 years of 'Delicious' strains and other cultivars on several rootstocks and hardy interstems. Fruit Var. J. 36:37-45.

Fisher, D.V. and D.O. Ketchie. 1981. Survey of literature on red strains of 'Delicious.' Washington State Univ. Agr. Res. Ctr., Pullman. Bul. 0898.

Fisher, D.V. and D.O. Ketchie. 1989. Survey of literature on red strains of 'Delicious'. Washington State Univ. Coop. Ext., Pullman. Bul. EB1515.

Fisher, D.V., M. Meheriuk, and J.E. Awales. 1970. Spur and standard 'Delicious' strains compared. British Columbia Fruit Grower Assn. Quarterly Rpt. 14:7-19.

Idaho Agricultural Statistics Service. 1991. Idaho agricultural statistics. Idaho Agr. Stat. Serv., Boise.

Ingle, M. 1972. Studies on the maturity and storage behavior of Red Delicious bud sports. West Virginia Agr. Expt. Sta., Morgantown. Bul 609T.

Ketchie, D.O. 1984. Flowering, spur formation and limb angles of Delicious apple strains. Fruit Var. J. 38:150-152.

Lord, W.J., R.A. Damon, Jr., and J.F. Anderson. 1980. A comparison of tree size, productivity, and fruit quality of 'Delicious' strains. J. Amer. Soc. Hort. Sci. 105:883-887.

Singha, S., E.C. Townsend, and T.A. Baugher. 1991. Relationship between visual rating and chromaticity values in 'Delicious' apple strains. Fruit Var. J. 45:33-36.

Tukey, R.B. and J.K. Ballard. 1969. Characteristics of Delicious apple strains and selections. Washington State Univ. Agr. Coop. Ext. Serv., Pullman. Bul. EM 3124.

Warrington, I.J., D.C. Ferree, J.R. Schupp, F.G. Dennis, Jr., and T.A. Baugher. 1990. Strain and rootstock effects on spur characteristics and yield of 'Delicious' apple strains. J. Amer. Soc. Hort. Sci. 115:348-356.

Westwood, M.N. 1963. Some differences in growth, chemical composition and maturity between a spur mutant and standard-growing 'Delicious' apples. Proc. Washington State Hort. Dig. 21:72-74.

Westwood, M.N. 1967. Differences in growth, chemical content and fruit set among four sports of 'Delicious' apples. Fruit Var. Hort. Dig. 21(4):72-74.

Westwood, M.N. and D.J. Burkhart. 1968. Climate influences shape of 'Delicious'. Amer. Fruit Grower 88:26. 